\title{
Intencionalidade, jornalismo opinativo e leitura
}

Luiz Antonio Ferreira ${ }^{1}$

Os caminhos da leitura na escola estão sendo repensados por muitos estudiosos e, assim, a função hermenêutica da retórica ganha corpo cada vez mais expressivo quando a concebemos, como o faz Olivier Reboul (1998) em sua obra Introdução à Retórica, que para ser bom orador - e, completamos, bom leitor - é preciso saber a quem se está falando (ou quem fala), não se deter no texto, mas ir além e compreender o discurso com suas intenções manifestas ou latentes, a fim de detectar as possíveis ciladas, de sopesar as forças de seus argumentos e sobretudo de captar o não-dito. Vista pelo prisma heurístico, por sua vez, a retórica admite que a verdade raramente é evidente e, assim, seu papel seria também o da descoberta. Nessa perspectiva, é possível retomar em Maingueneau a afirmação de que cada discurso estabelece seu tom por meio de uma voz que repousa na figura do orador e de seu ethos. Ao leitor, compete buscar, na materialidade da linguagem e no contexto, os sentidos possíveis pela identificação precisa das estratégias persuasivas. Tendo por base o discurso jornalístico, este texto pretende associar os conceitos da pragmática discursiva, ou especificamente o de intencionalidade local e global, de Anne Reboul e Moeschler, com os estudos da retórica de Perelman e de Olivier Reboul a fim de contribuir para os estudos que pretendem a busca de caminhos para uma pedagogia da leitura capaz, sobretudo, de ampliar a criticidade pelo desvendamento das estratégias utilizadas no conjunto de traços de

${ }^{1}$ Professor de Lingüística da Pontifícia Universidade Católica de São Paulo, PUC-SP. 
operações da enunciação.

Para a realização desses objetivos, valemo-nos, como artifício didático, de um texto jornalístico opinativo, denominado "Carta a um Jovem Repórter", publicado em 21 de maio de 1998, na Folha de São Paulo, assinado por Jorge da Cunha Lima, jornalista e escritor, de sessenta e cinco anos, identificado no rodapé como presidente da Fundação Padre Anchieta, mantenedora da TV Cultura. O texto tematiza o confronto entre duas visões jornalísticas, uma antiga e outra moderna, com evidente viés opinativo favorável à tradição. Essas categorias, modernidade e tradição, convivem em qualquer sociedade, coabitam em qualquer época e, por isso, independentemente da posição do orador, dão pistas ao auditório de um modo de entender a experiência humana e, sobretudo, permitem entender como se legitimam os discursos, os modos de vida e os comportamentos. Essas duas categorias motivam, no plano temático, o autor a analisar duas posturas possíveis: a da paixão (supostamente necessária ao repórter) e a que a esta se contrapõe, a da exacerbada visão crítica de mundo, que privilegia o plano da relevância da informação:

Tenho minhas dúvidas de que um repórter sem paixão possa prestar serviço relevante ao jornal em que trabalha. Na falta de paixão, sobra-te uma visão crítica do mundo, o que não é mau em si, mas se torna deletério no abuso.

Essa afirmação nasceu de um comentário primeiro do repórter, como mostra o parágrafo a seguir:

Outro dia, um jovem repórter dizia-me, com grande convicção, que mantém sempre distância absoluta dos fatos e das pessoas, uma clara neutralidade diante do sujeito e do objeto, para ser justo nas suas reportagens.

Evidentemente, o repórter dá mostras de crenças adquiridas durante sua formação. A partir daí, o jornalista mais experiente desencadeia uma discussão que põe em xeque tanto a função do jornalista no mundo contemporâneo quanto o lugar da razão e da afetividade em nossos dias. A afirmação do jovem repórter advém, por certo, de uma concepção de fazer jornalismo que, por sua vez, pode ter sido herdada do mito do objetivismo que dominou a cultura ocidental e, particularmente, a filosofia ocidental, dos pré-socráticos até nossos dias (racionalismo cartesiano, empirismo, filosofia kantiana, positivismo lógico). A razão na modernidade, diz-nos o estudioso da comunicação Adriano Duarte Rodrigues (1994), "desempenha o papel inquestionado de ponto de fuga da representação, de unificação dos saberes, pela indagação da natureza, dos modos de funcionamento do mundo e pela descoberta das leis que o regem" e, complementa, é o lugar invisível a partir do qual o mundo é posto em perspectiva. Contra essa postura cartesiana se insurge o experiente jornalista, ao propor uma nova ordem de representação que admite como também possível a construção subjetiva do real, como se percebe na seguinte afirmação: "Perdes, pela 
${ }^{2} \mathrm{~A}$ origem etimológica $e$ a evolução do termo tradição (do verbo latino tradere, composto de dare, dar ou transmitir entregar, e do prefixo trans-,

completamente, de um lado ao outro) é bastante sugestiva, uma vez que, em latim, traditio podia ser utilizado tanto para indicar uma ação de entregar ou de dar algo ou alguma coisa, quanto para uma narrativa ou história que relatasse acontecimentos supostamente passados. Uma outra acepção referia-se à traição, ato de entrega a um inimigo de alguém ou de alguma coisa. Traditor poderia ser tanto o mestre que transmite um ensinamento quanto o traidor que entrega às escondidas alguém a um inimigo.

Confundidas, na origem, a partir de um mesmo étimo, os termos tradição e traição ganharam contornos distintos a partir do século XIII. De qualquer modo, a palavra tradição ainda guarda resquícios do sentido primeiro, na medida em que não é um conhecimento exato e formalmente objetivável que a tradição transmite, mas, sim, algo que pertence à ordem da reminiscência, algo que os discursos podem trair ou deixam transpirar. neutralidade ascética, o juízo maior, que não se produz pela simples distância, mas por um contato muito próximo da razão e da sensibilidade com o assunto de tua reportagem."

O repórter, para Jorge da Cunha Lima, deveria posicionar-se como um analista da realidade, como um intérprete e não como mero reprodutor de fatos. Nesse sentido, parece concordar com Moeschler e Reboul quando solicitam que o intérprete focalize as intenções de todos os implicados num processo comunicativo e, assim, assuma uma postura cognitiva explicitamente intencionalista, justamente para ressaltar dois pontos fundamentais que levam em conta, primeiramente, o fato de os envolvidos na comunicação serem agentes racionais, e, depois, de os mesmos agentes serem dotados de crenças, desejos e outros estados mentais. Os parágrafos iniciais da "carta" são bastante enfáticos nesse sentido:

Ao falar isso com um certo orgulho, mas sem brilho nos olhos, deume a impressão de se tratar do cultor de uma língua que só admitisse predicados, de uma justiça que dispensasse toda afetividade ou de uma crítica incapaz de se comprometer.

Pois és, jovem repórter do primeiro parágrafo, o mais vulnerável dos "focas". É bem provável que tenhas lido com fervor reverencial o manual de redação mais próximo, mas tua contribuição ao jornal talvez não vá muito além do computador que usas para promover a justiça factual de cada dia.

O jornalista, então, lê o fato ocorrido e o transforma, pelo processo de comunicação, em fato informado. E o faz pelo discurso que, por sua vez, evidencia as inferências feitas a partir de seu repertório e visão de mundo. Pensar o discurso do dia-a-dia, que se transmuta em fato, seria, então, um exercício de compreensão e de inferências que advêm da dinamização de fenômenos diversos, capazes de revelar parte do repertório e das experências de determinado sujeito, como bem pontuam Moeschler $e$ Reboul. Ressalte-se que a mesma postura investigativa seria desejável no leitor.

Pautando-se nos considerados "notáveis", Jorge da Cunha Lima justifica sua posição favorável a um jornalismo outro, que se interponha à corrente objetivista apregoada pelo jovem repórter:

No meu percurso de jornalista, conheci três notáveis, que pouco se enquadrariam nessa neutralidade justiceira que professas hoje.

Exerciam a sua profissão com a mesma ética diante do poder, da autoridade ou da miséria explícita. Tinham a paixão na medula, embora fossem tão diversos - quase opostos, se confrontados.

O apoio explícito do velho jornalista vincula-se a uma espécie de valorização ético-humanística encontrada em tradição ${ }^{2}$ bastante recente, uma vez que limita a argumentação ao "seu" percurso de jornalista. Sua fala pretende ressaltar a intencionalidade, a paixão dos velhos jornalistas, 
envoltos numa prática de natureza dissertativo-expositiva e, por isso, dotada de intencionalidade enunciativa, capaz de traduzir e até de trair quando as crenças éticas do orador esconderem, para ele mesmo, as outras faces de uma suposta verdade. O interesse real do jornalista estaria no investigar a significação do fato que comenta. Enfim, seu interesse é negociar os sentidos.

Quer nos parecer que, embora não o diga explicitamente, Cunha Lima confia na capacidade interpretativa do leitor, capacidade de entender a intencionalidade do jornalista diante dos fatos e que, por meio de um processo de interpretação, ambos devem ser capazes de chegar às suas próprias conclusões. Há, nessa suposta crença, uma visão de leitura como evento social (Bloome, 1993), como um processo que permite ao indivíduo orientar a si e aos outro, controlar a si e ao outro, comunicar o que pensa $e$ sente por meio da negociação dos sentidos possíveis de um texto ou de vários, postos em relação intertextual.

Cabe, neste momento, refletir, ainda que brevemente, sobre algumas questões ligadas à educação e à formação de leitores. O jovem repórter, em seu discurso, está convicto de que procede muito bem ao evitar, a qualquer custo, o aspecto subjetivo, o sinal mínimo de envolvimento emocional para ressaltar o aspecto racional e frio da análise estrita do fato. Querendo informar, pretende instaurar uma espécie de observação supostamente científica da realidade. O velho jornalista, por seu turno, ressalta que no centro do processo de profissionalização não está o fazer, mas o saber-fazer $e$ isso seria muito mais do que o exercício rotineiro de um ofício, já que admite a reinvenção constante, movida por um impulso capaz de lançar um olhar valorativo sobre os fatos, sem abandonar a visão de mundo do orador ou do auditório. Enfim, o que Cunha Lima reclama do repórter é o que se exige de um leitor proficiente: capacidade para descobrir o tom de cada discurso, desvendar na voz do orador o seu ethos. De acordo com esse raciocínio, cabe ao leitor a interpretação, cabe ao leitor saber que " $a$ idéia de uma linguagem idealmente transparente às coisas não é verdadeira nem mesmo para o discurso mais comum, já que a enunciação deixa sempre seu vestígio no enunciado e que a linguagem só pode designar designando-se" (Maingueneau, 1996).

Assim, a neutralidade do repórter seria apenas um mito. Escrever para um jornal como um ato que procura fazer crer que o que se diz é verdadeiro, é simplesmente um ato ou esforço retórico. Ao leitor compete saber por que meios um discurso é persuasivo para dar o efeito de verdade. Como afirma Olivier Reboul (1998, XVII), esses meios são de ordem racional alguns, de ordem afetiva outros, já que em Retórica, razão e sentimento são inseparáveis.

Os meios de competência da razão fundam-se no argumento, nem sempre lógicos, como bem nos mostra Perelman (1996); os meios que dizem respeito à afetividade centram-se em dois pólos distintos e complementares: de um lado o ethos, o caráter que o orador assume e demonstra para chamar a atenção e angariar a confiança do auditório; de outro, o pathos, as tendências, os desejos, as emoções do auditório das quais o orador procura tirar partido. 
Jorge da Cunha Lima procura dar essa visão ao jovem jornalista quando, ao referir-se a Júlio Mesquita Filho, diz:

\author{
Tomava partido o tempo todo, falava e escrevia em nome dos seus \\ princípios, desconhecia a neutralidade. Tinha enorme afeto pelas \\ pessoas, inclusive adversários ideológicos, que abrigava com \\ generosidade em seu jornal. Era amado e odiado, mas morreu \\ respeitado como grande jornalista.
}

O experiente jornalista procura mostrar ao jovem repórter a existência de um conceito outro de competência humana, que pode aliar, num todo orquestrado, razão e emoção, e que é necessário fazer da disponibilidade de aprender, apreender e sentir o centro da atuação profissional. Evidentemente, tais habilidades não são mágicas, mas, sim, processuais. Nesse sentido, a escola muito poderia contribuir. Se tivéssemos alternativas mais sólidas para ensinar a ler e para permitir que o educando construísse o seu percurso de leitura, encontraríamos meios de evidenciar que mais do que trilhar rotineiramente e com absoluta segurança caminhos certos do texto, é possível ler discursos para recriar efeitos de sentido, ler para descobrir como o discurso do outro, constituido de diversos planos, reproduz a variedade do mundo e sobretudo a polarização do pathos e do logos.

$\mathrm{O}$ ato de ler, então, assume outras proporções, pois, no plano fenomenológico, encaminharia o indivíduo para o pensar como ato de descoberta permanente. Não há, pois, "modelos", mas produção interacional de percepção e conhecimento. Ler, nesse sentido, seria um processo de aprender e diz respeito a habilidades ligadas ao ato de sentir, interrogar, raciocinar para entender. Em outro plano, o pedagógico, ler envolveria a capacidade de desenvolver no educando a habilidade de intervir na realidade de modo crítico e criativo, uma face que leva em conta a formação do cidadão e que, com base na capacidade de análise e compreensão para além do plano formal, pode moldar o sujeito histórico e o habilitar a criar e viver

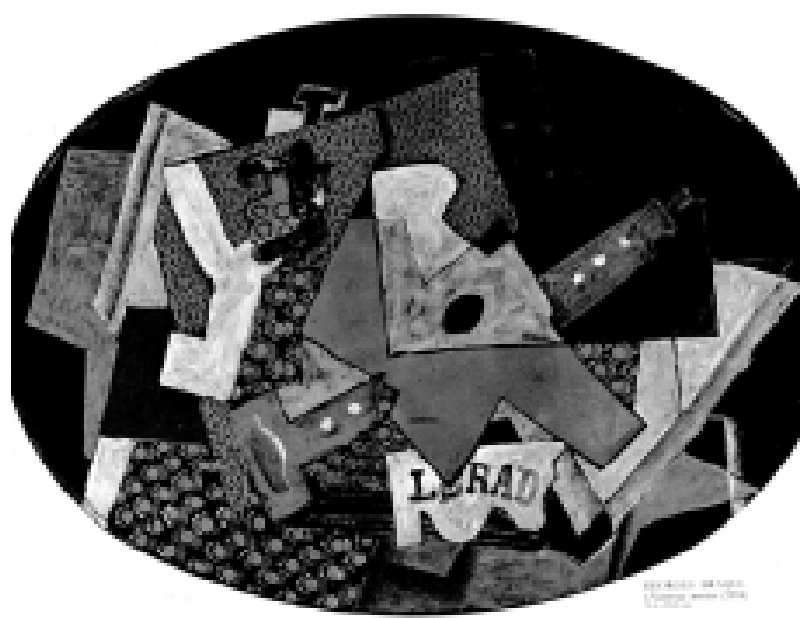

GEORGES BRAQUE, Natureza Morta, 1918. Instituto de Arte de Chicago. 
consciente e produtivamente, ao mesmo tempo, sua história própria e a coletiva. Outras habilidades como a da livre emoção (que permite o envolvimento subjetivo) e a de transferir para demonstrar concretamente o saber pensar são requeridas nesse processo. Assim, no percurso desse descobrir permanente o educando estaria sendo encaminhado para uma aprendizagem realmente efetiva, para um aprender que não conseguiria descansar sobre esquemas feitos, prémoldados, pré-determinados, como há tanto tempo costuma acontecer na escola. Ler, nessa perspectiva, implicaria o desaparecimento da visão "treineira" da leitura que teima em habitar nossas escolas. Expressões como "criar hábito de leitura" , "incentivar a prática de leitura" podem esconder uma concepção de leitura ligada ao fazer repetitivo, ligada ao desejo de treinar sempre e com tal intensidade que a resposta seja invariavelmente um bem repetir que, convenhamos, é uma técnica nem sempre educativa. $O$ ato de ler, assim, seria um fenômeno que permitiria constantemente a recriação, que poderia ser ampliado constantemente pelo desejo de julgar com parcimônia e conhecimento de causa, pois o julgar é produto de avaliação e apreciação dos aspectos constitutivos $e$ persuasivos do texto e do discurso que o sustenta. Ler, nesse sentido, seria demonstração cabal de que toda a leitura tem um propósito: lemos para deleite de nosso espírito, lemos para fazer resenhas na universidade, lemos para resumir e lemos, sobretudo, para entender o outro, seus desejos, suas habilidades discursivas, suas técnicas persuasivas.

Referências bibliográficas

BLOOME, D., EGAN-ROBERTSON, A. The social construction of intertextuality in classroom: reading and writing lessons. Read. Res. Quart., v.28, n.4, p.48-55, 1993.

MAINGUENEAU, D. Pragmática para o discurso literário, São Paulo: Martins Fontes, 1996.

PERELMAN, C., OLDEBRECTHS-TYTECA, L. Tratado da argumentação - a nova retórica. São Paulo: Martins Fontes, 1996.

REBOUL, A., MOESCHLER. Pragmatique du discours: de l'interpretation de l' énoncé à l' ínterpretation du discours. Paris: Armand Colin, 1998.

REBOUL, O. Introdução à retórica. São Paulo: Martins Fontes, 1998.

RODRIGUES, A. D. Comunicação e cultura: a experiência cultural na era da informação. Lisboa: Presença, 1993.

PALAVRAS-CHAVE: jornalismo; leitura; comunicação persuasiva. KEY WORDS: journalism; reading; persuasive communication. 